\title{
PRIMARY CREEP OF STRUCTURAL STEEL (SS 41) AT HIGH TEMPERATURES
}

\author{
By Morihisa FUJIMOTO*, Fukujiro FURUMURA** \\ Takeo AVE*** and Yasuji SHINOHARA***** \\ Members of A.I.J.
}

\begin{abstract}
Results of a primary creep study conducted on structural steel (SS 41) specimens in tension are presented. These specimens were subjected to various constant loads and high temperatures from 350 to $600^{\circ} \mathrm{C}$ for 6 hours. Also presented is a mathematical expression, shown in a term of product of exponential functions with material constants. The expression is originally based on that developed by Nishihara and others, and modified by authors to suit more wide range of stress level and temperature. Besides, the stress-strain curves obtained together with creep curves are shown, and the correlation between creep strain and elastic-plastic strain is clarified by these curves.
\end{abstract}

\section{INTRODUCTION}

Because of the great concentration of people and property in highrise buildings, the potential risk of large loss of life and property due to fire must be minimized. Traditionally structural engineers have accepted in their fire safety design the guidance of the minimum requirements of existing fire protection standards of building standard law. According to the standards, the fire safety performance of structural elements are evaluated by the Standard Furnace Fire Test, Japanese Industrial Standard (JIS) method A 1304. This is a haphazard procedure, as the standard furnace fire endurance of structural elements has little relation to the structural element endurance in an actual compartment fire. The standard furnace fire test results, though obtained at great cost, do not contribute to the understand ing of the behavior of structural elements in an elevated temperature environment and cannot be applied rationally in fire safety design. The response of a highrise structure in a fire is a very complex problem. A rational analysis of the problem requires the solution to some basic tasks. It is one of these basic tasks that the time deformation and thermal creep behavior of the steel structure can be determined according to the temperature dependent material properties. A great deal of research result is available for the design of structures such as turbine and nuclear reactors to determine the long-term creep deformation behavior at constant elevated temperature. Very little is known, however, for high-rise structures in fire in which the creep process is relatively short term but with high temperature rate. The success of analyzing the behavior of steel structures in a fire depends on how accurately certain mechanical properties, especially creep of steel, are known in the 350 to $600^{\circ} \mathrm{C}$ temperature range ${ }^{(1)(2)(3)(4)}$. Then, the main purpose of this study is to make clear the creep behavior and relationship between creep strain and elastic-plastic strain of structural steel, SS 41 . The work is confined to a study of creep behavior of steel under constant load and temperature.

\section{SPECIMENS}

Structural steel, SS 41, were used. The steel specimens were cut out from steel plates of $25 \mathrm{~mm}$ thickness in the same direction as that of hot rolling. The size of specimen is shown in Fig. 1. The

* Dr. Eng., Professor, Tokoyo Institute of Technology.

** Dr. Eng., Associate Profəssor, The Research Laboratory of Engineering Materials, Tokoyo Institute of Technology.

*** Graduate Student, Tokoyo Institute of Technology.

**** Division of Structural Design, Mitsubishi Heavy Industry Co. Ltd. 
mechanical property and the chemical composition of steel are given in Tables 1 and 2. The gauge length is $50.8 \mathrm{~mm}$.

\section{TESTING PROCEDURE}

Creep tests were carried out on a universal screw-power testing machine equipped with an electric fuanace (See Fig. 2): The temperature of the furnace was controlled by a time-proportioning, integrating and differenciating controller. Special tensile tools were designed and made from heat resisting steel for transferring the load from the crosshead of the testing machine to the specimen within the furnace. The differential transformer of the deformation recording system was mounted underneath the furnace on small aluminum holders. These were fastened with screws to four extension arms which were tightened through springs with screws to the specimen. A specimen with the loading assembly and high temperature extensometer are shown in Figs. 2 and 3 . To minimize the circulation of air inside the furnace the gap between the stem of the loading tools and the furnace was partially filled with a fibrous and a boardlike insulation. Each specimen was tested at high temperatures which covered the 350 to $600^{\circ} \mathrm{C}$ temperature range at $25^{\circ} \mathrm{C}$ increments. The applied stresses at each temperature were 3 to 5 levels at $2.5 \mathrm{~kg} / \mathrm{mm}^{2}$ increments. As a general rule, one specimen was tested at each temperature and stress level for 6 hours. The whole test conditions of steel specimens are give in Table 3.

\section{TEST RESULTS}

The typical creep and stress-strain curve obtained on the recorder of the testing machine is shown in Fig. 4. The stress-strain curves obtained at high temperatures are shown for reference in Fig. 5 . The tensile test conditions are given in Table 4 and mechanical properties at high temperatures is shown in Table 5. The creep curves of structural steel, SS 41, are shown in Figs. 6 and 7 . In these figures, the mark, - shows the strain when stress was increased to the appointed level. Some examples of the stress-strain curves obtained together with creep curves are shown in Fig. 8. In these figures, the horizontal straight lines show the creep strains and the curves following them show the stress-strain curves obtained after the finish of creep tests. From these figures, the relationship between creep strain and elastic-plastic strain is clarified, that is, the stress-strain curves arises with the same gradient as the initial tangent and follows the virgin stress-strain curve with a short interval at low level of stress. Creep strain in effected by stress, temperature and time. The influence of time on the

Table 1 Chemical composition $(\varphi \circ)$

\begin{tabular}{|c|c|c|c|c|c|}
\hline JIS & C & Si & Mn & P & S \\
\cline { 2 - 6 } grade & \multicolumn{3}{|c|}{$\times 100$} & \multicolumn{2}{|c|}{$\times 1000$} \\
\hline SS 41 & 18 & 24 & 73 & 16 & 17 \\
\hline
\end{tabular}

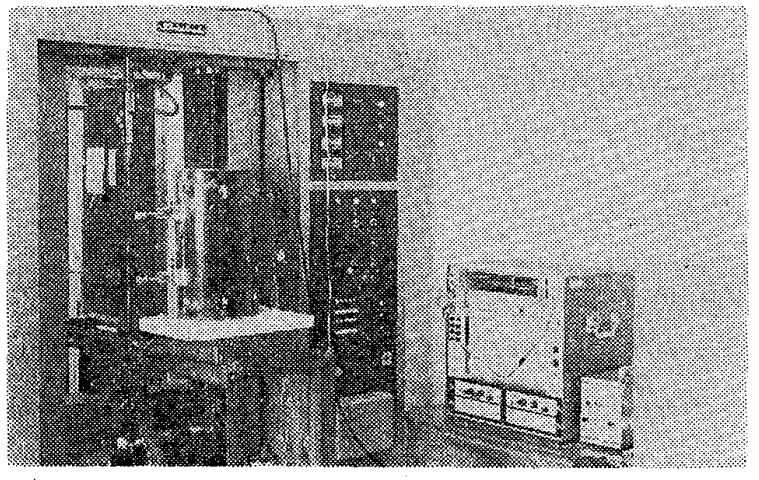

Fig. 2 General view of the testing machine with furnace and loading assembly

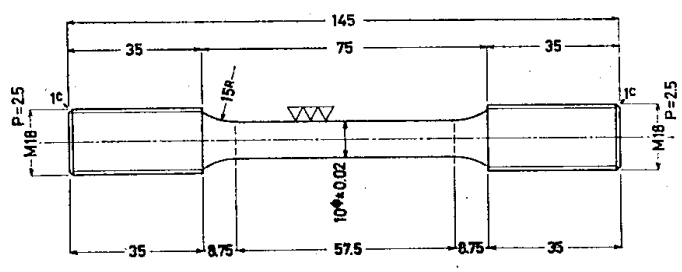

Fig. 1 Shape and size of a specimen

Table 2 Mechanical properties

\begin{tabular}{|c|c|c|c|}
\hline $\begin{array}{c}\text { JIS } \\
\text { grade }\end{array}$ & $\begin{array}{c}\text { Yield Point } \\
\left(\mathrm{kg} / \mathrm{mm}^{2}\right)\end{array}$ & $\begin{array}{c}\text { Tensile Strength } \\
\left(\mathrm{kg} / \mathrm{mm}^{2}\right)\end{array}$ & $\begin{array}{c}\text { Elongation } \\
(\%)\end{array}$ \\
\hline SS 41 & 24.89 & 44.0 & 38.0 \\
\hline
\end{tabular}

Table 3 Creep test conditions

(5S 41)

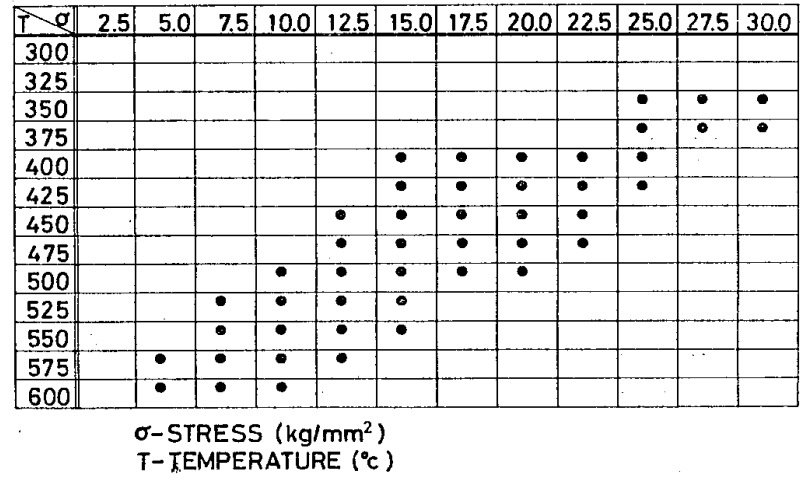




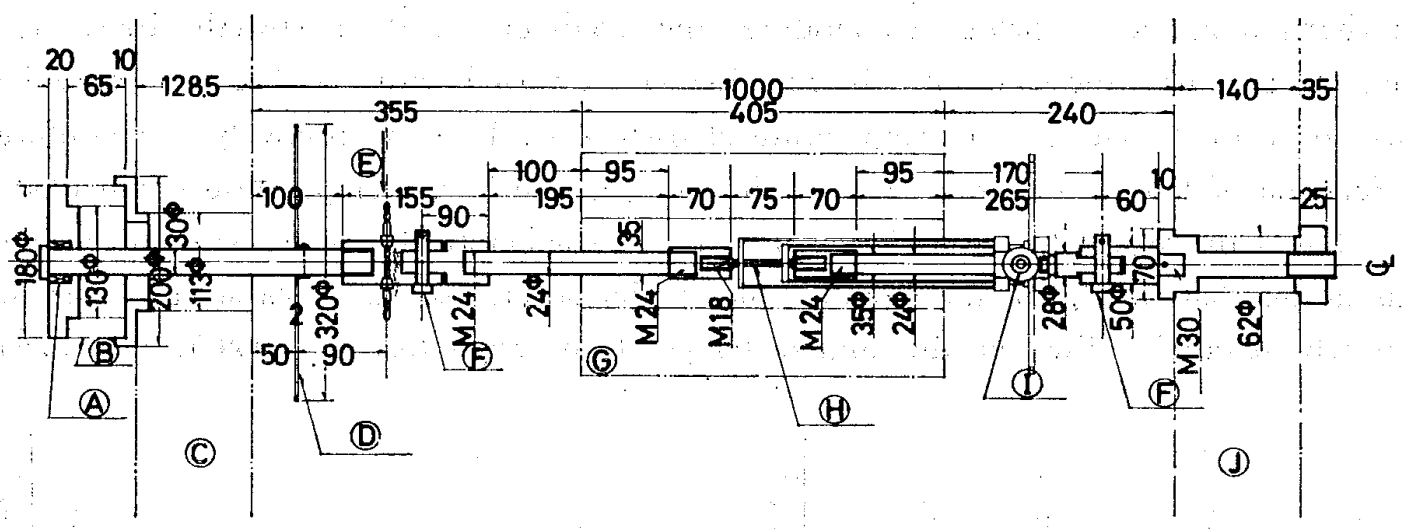
A; Spherical Bearing
B ; Load cell
F; Pin
C ; Upper crosshead
D; Heat insulating plate
G; Furnace
$\mathrm{H}$; Specimen
$\mathrm{E}$; Coaling water
I ; High temperature
$\mathrm{J}$; Lower crosshed

Fig. 3 Detailes of the loading assembly and extensometer

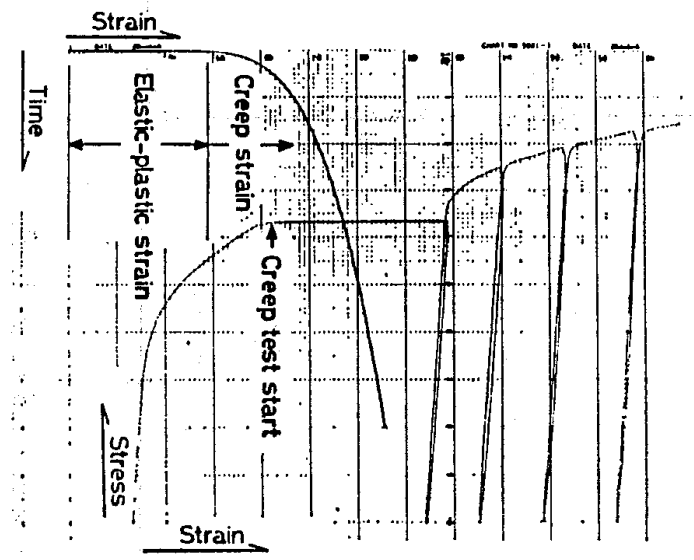

Fig. 4 Tipical creep and stress-strain curve obtained on the recorder (SS $41,475^{\circ} \mathrm{C}, 20.0 \mathrm{~kg} / \mathrm{mm}^{2}$ )

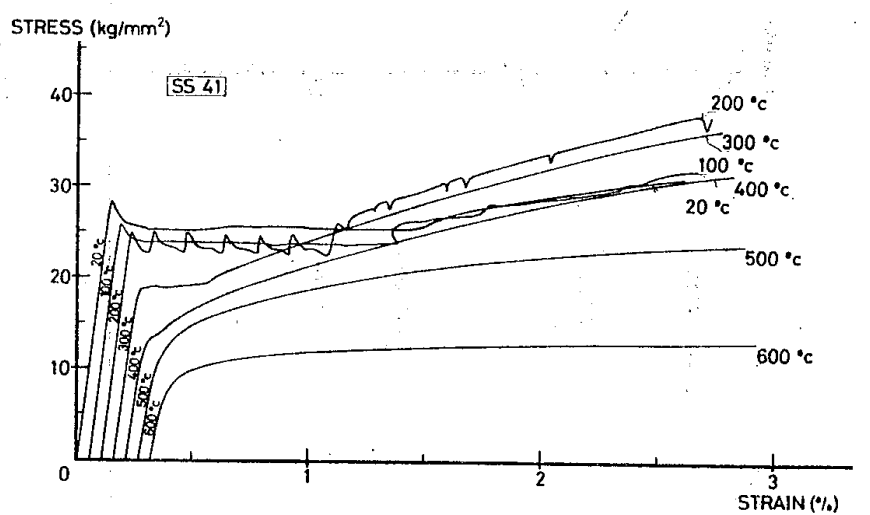

Fig. 5 Stress-strain curvce of steel at high temperatures primary creep of structural steel was great within 30 minutes from the start of creep test. The creep strain was greatly affected at higher temperature than $450^{\circ} \mathrm{C}$ and therefore cannot be ignored at analyzing the thermal stress of structure in fire. Besides, with regard to stress, creep strain was very increased when the stress level was greater than the proportional limit.

\section{MATHEMATICAL EXPRESSION}

Fig. 9 show the relationship between creep strain and time in log-log scale. From these figures, it is understood that the relation between the logarithmic creep strain and the logarithmic time is approximately linear at each temperature and stress level, and is expressed as follows;

$$
\varepsilon_{c}=10^{A} t^{n}
$$

where $\varepsilon_{c}$ is creep strain, $t$ is time and $A$ and $n$ are constants. When the stress
Table 4 Tensile test conditions

\begin{tabular}{|c|c|c|c|c|c|c|c|}
\hline $\mathrm{G}-\mathrm{T}$ & R.T. & 100 & 200 & 300 & 400 & 500 & 600 \\
\hline SS 41 & $\bullet$ & - • & & & & & - $\bullet$ \\
\hline
\end{tabular}

G; JIS grade

$\mathrm{T}$; Temperature $\left({ }^{\circ} \mathrm{C}\right)$

R.T.; Room temperature

Table 5 Yield strength and modulus of elasticity

\begin{tabular}{|c|c|c|}
\hline \multirow{2}{*}{ G } & \multicolumn{2}{|c|}{ SS 41 } \\
\hline R.T. & $\begin{array}{c}\text { Yield Strength } \\
\left(\mathrm{kg} / \mathrm{mm}^{2}\right)\end{array}$ & $\begin{array}{c}\text { Modulus of Elasticity } \\
\left(\times 10^{4} \mathrm{~kg} / \mathrm{mm}^{2}\right)\end{array}$ \\
100 & 24.89 & 2.15 \\
200 & 23.69 & 2.03 \\
300 & 22.32 & 2.07 \\
400 & 18.69 & 1.86 \\
500 & 16.52 & 1.87 \\
600 & 15.47 & 1.60 \\
\hline
\end{tabular}

G; JIS grade

T; Temperature $\left({ }^{\circ} \mathrm{C}\right)$

R.T.; Room Temperature

Table 6 Material constant

\begin{tabular}{|c|c|c|c|c|c|c|}
\hline $\begin{array}{c}\text { JIS } \\
\text { grade }\end{array}$ & $\mathrm{a}$ & $\mathrm{b}$ & $\mathrm{c}$ & $\mathrm{d}$ & $\mathrm{e}$ & $\mathrm{f}$ \\
\hline $\mathrm{SS} 41$ & $-7.45 \times 10^{3}$ & 3.71 & $1.78 \times 10^{3}$ & 1.82 & $6.47 \times 10^{-4}$ & $-1.51 \times 10^{-1}$ \\
\hline
\end{tabular}


levels are changed at each constant temperature, the gradients of these straight lines also changed. Fig. 10 and 11 show how the constant $n$ in equation (1) is varied with the change of stress level at each temperature, or with the change of temperature at each stress level, respectively. Therefore, $n$ is in general a function of temperature and stress. However, at the lower temperature range $\left(350\right.$ to $\left.500^{\circ} \mathrm{C}\right)$, the change of $n$ with regard to the variation of stress is comparatively small for each constant temperature. This means that in Fig. 9, the straight lines under several stress levels at each constant temperature are nearly parallel. But, at the higher temperature range $\left(525\right.$ to $\left.600^{\circ} \mathrm{C}\right)$, the variation of $n$
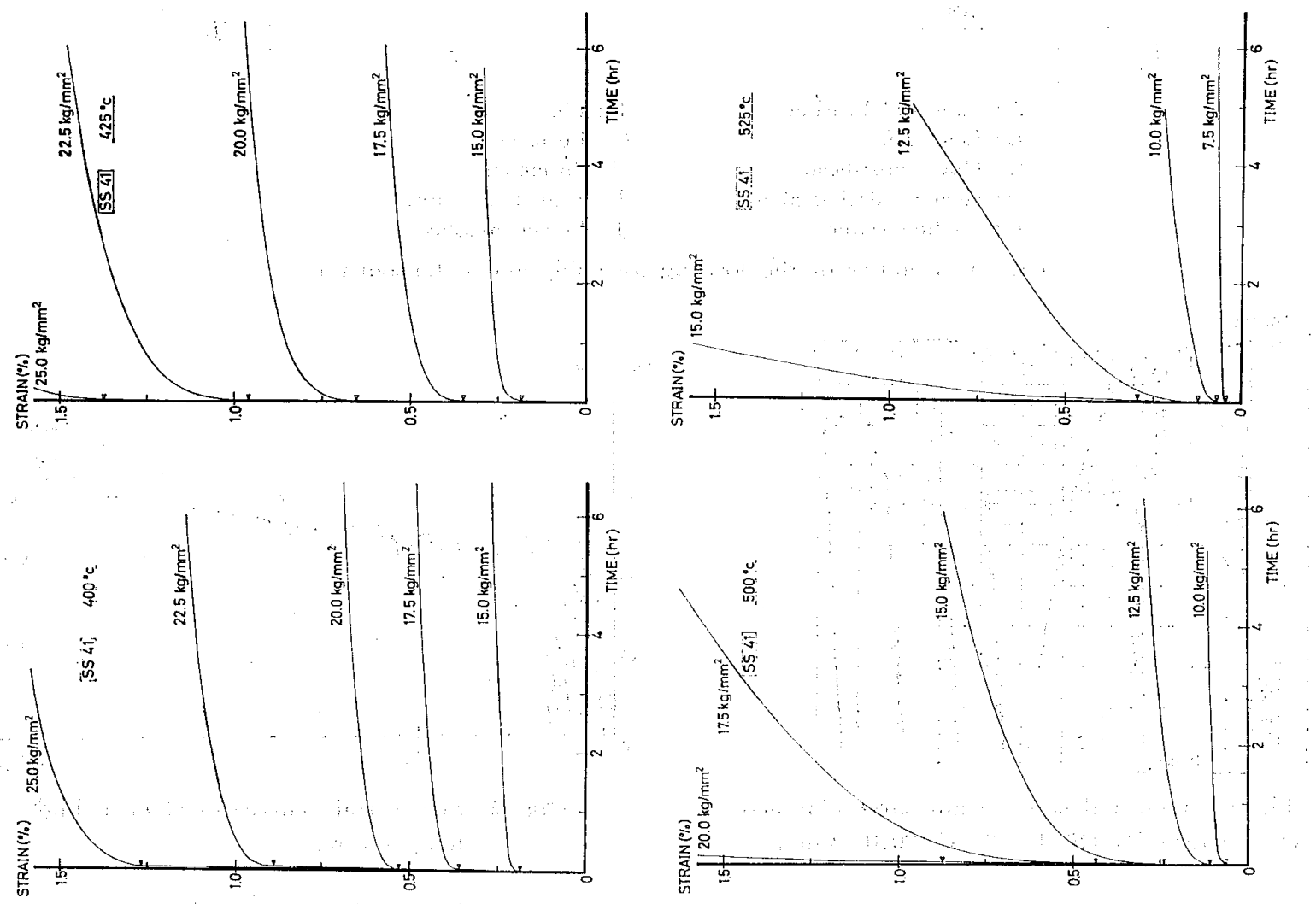

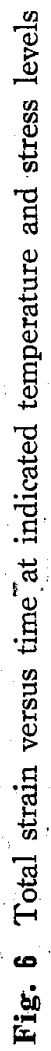
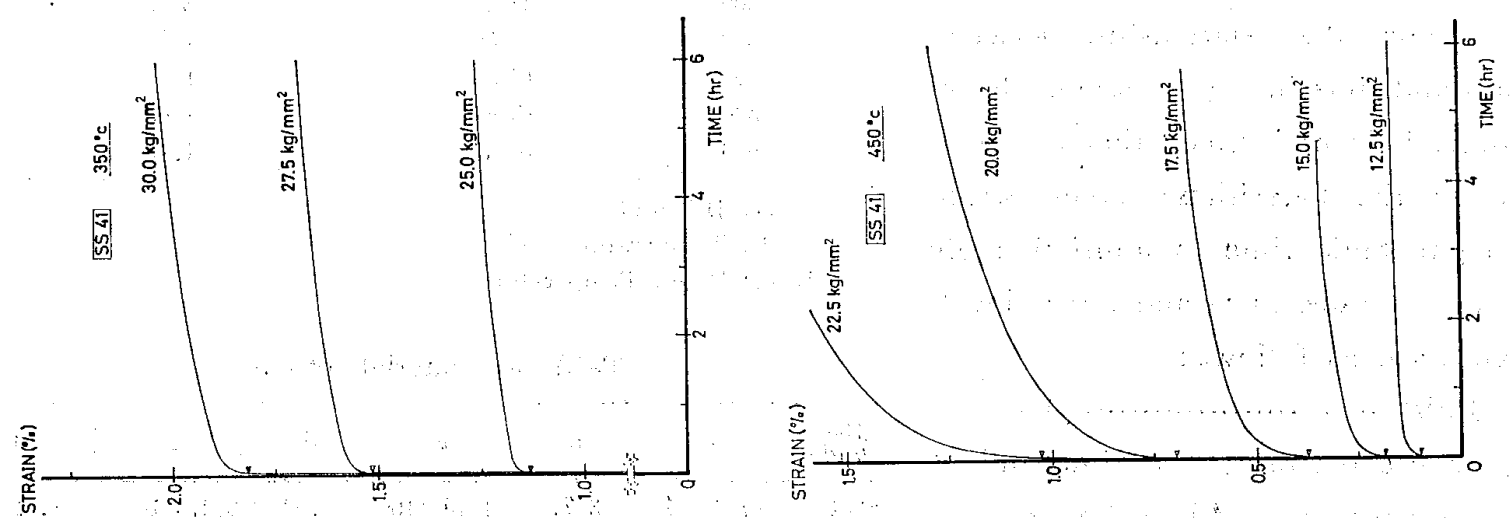

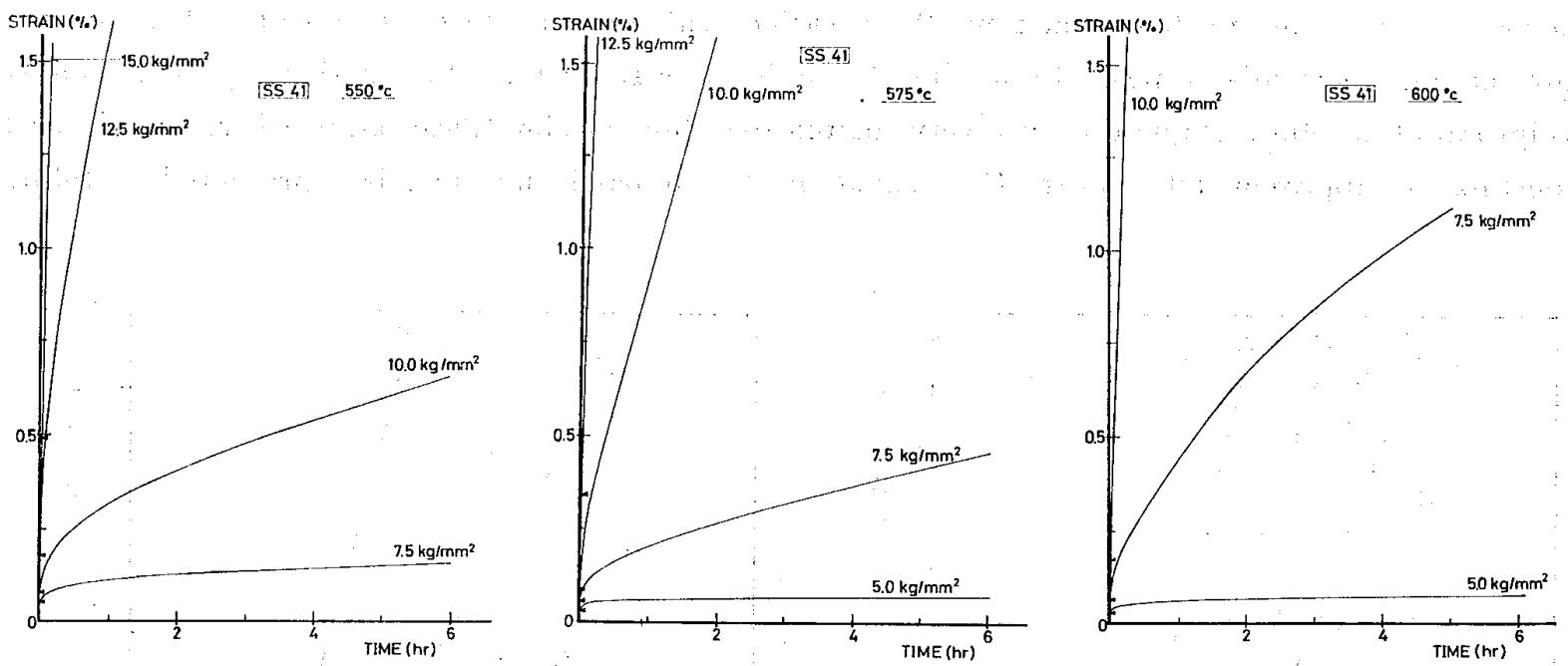

Fig. 7 Total strain versus time at indicated temperature and stress levels

regarding stress is considerably large. Fig. 12 show the relationships between creep strains and stress under several constant temperatures at some particular times. From these figures, it is clari fied that the logarithmic creep strain is approximately linear with respect to the logarithmic stress at each particular time under constant temperatures. The mathematical expression for the prediction of creep strain, $\varepsilon_{c}$, under arbitrary stress levels at constant temperature are, therefore, as follows;

$$
\varepsilon_{c}=10^{A} \sigma^{B} t^{n}
$$

wheae $\sigma$ is stress, $t$ is time, $A$ and $B$ are constants and $n$ is a function of stress.

On the other hand, the relationships between the logarithmic creep strains and the reciprocal of absolute temperatures under several stress levels at particular times are not always considered to be linear as shown in Fig. 13. However, if it could be assumed that these relationships were approximately linear for simplification, $A$ in equation 2 under constant stress at particular time is represented as follows;

$$
A=\frac{a}{T}+b
$$

where $T$ is absolute temperature, and $a$ and $b$ are constants.

Besides, if it could be assumed that the relationships between logarithmic creep strains and logarithmic stress at each particular time undex constant temperatures were approximately linear (See Fig. 12), B in equation (2), at particular time under constant temperatures is obtained as the gradient of these straight lines. Fig.
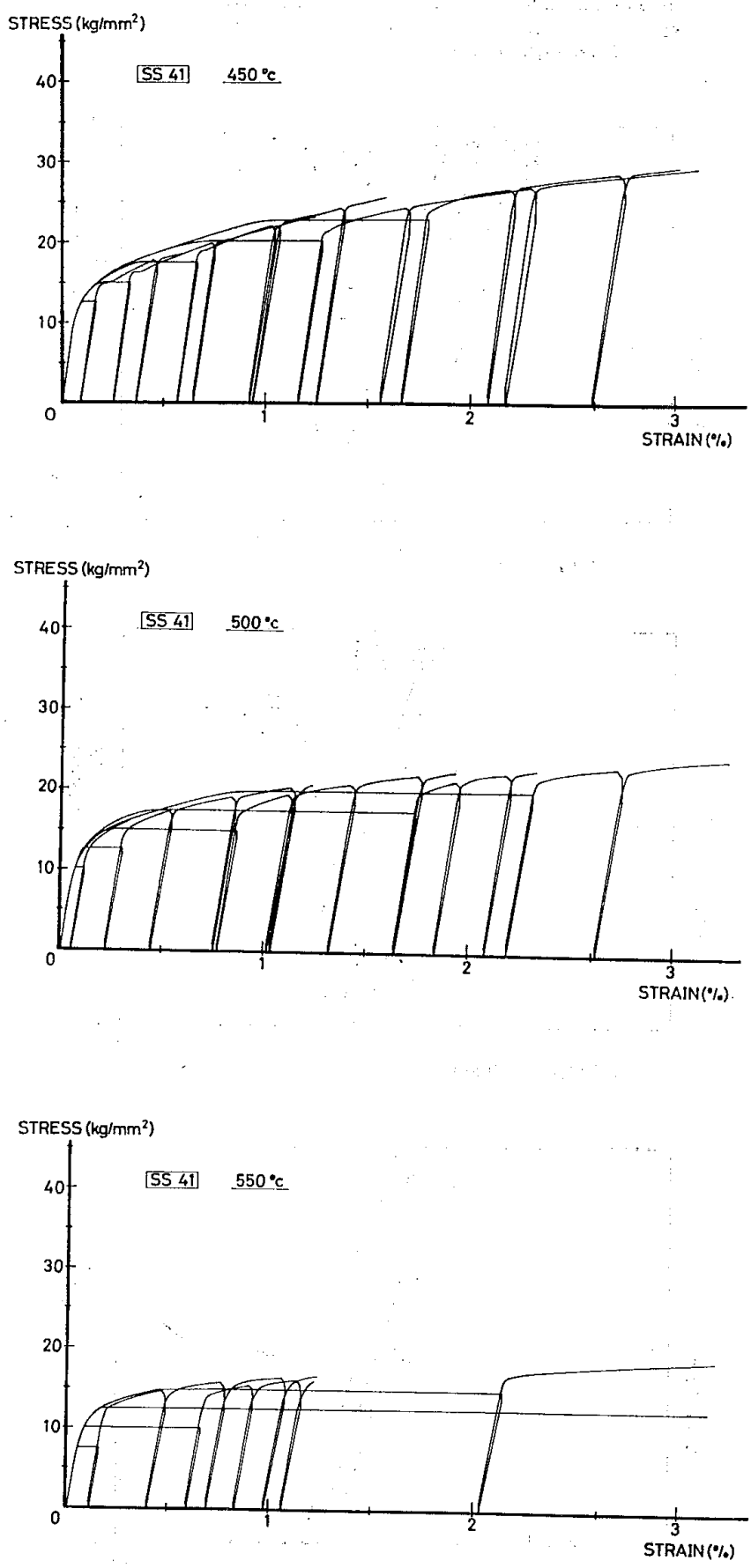

Fig. 8 Stress-strain curves obtained at creep test 
14 shows how the constant $B$ in equation (2) is varied with the change of reciprocal of absolute temperature at some particular times. From Fig. 14, it is understood that the relationships between $B$ and the reciprocal of absolute temperature are very complicated, but for simplification, if it is assumed that these relationships are approximately linear, $B$ in equation (2), at particular time is represented as follows;
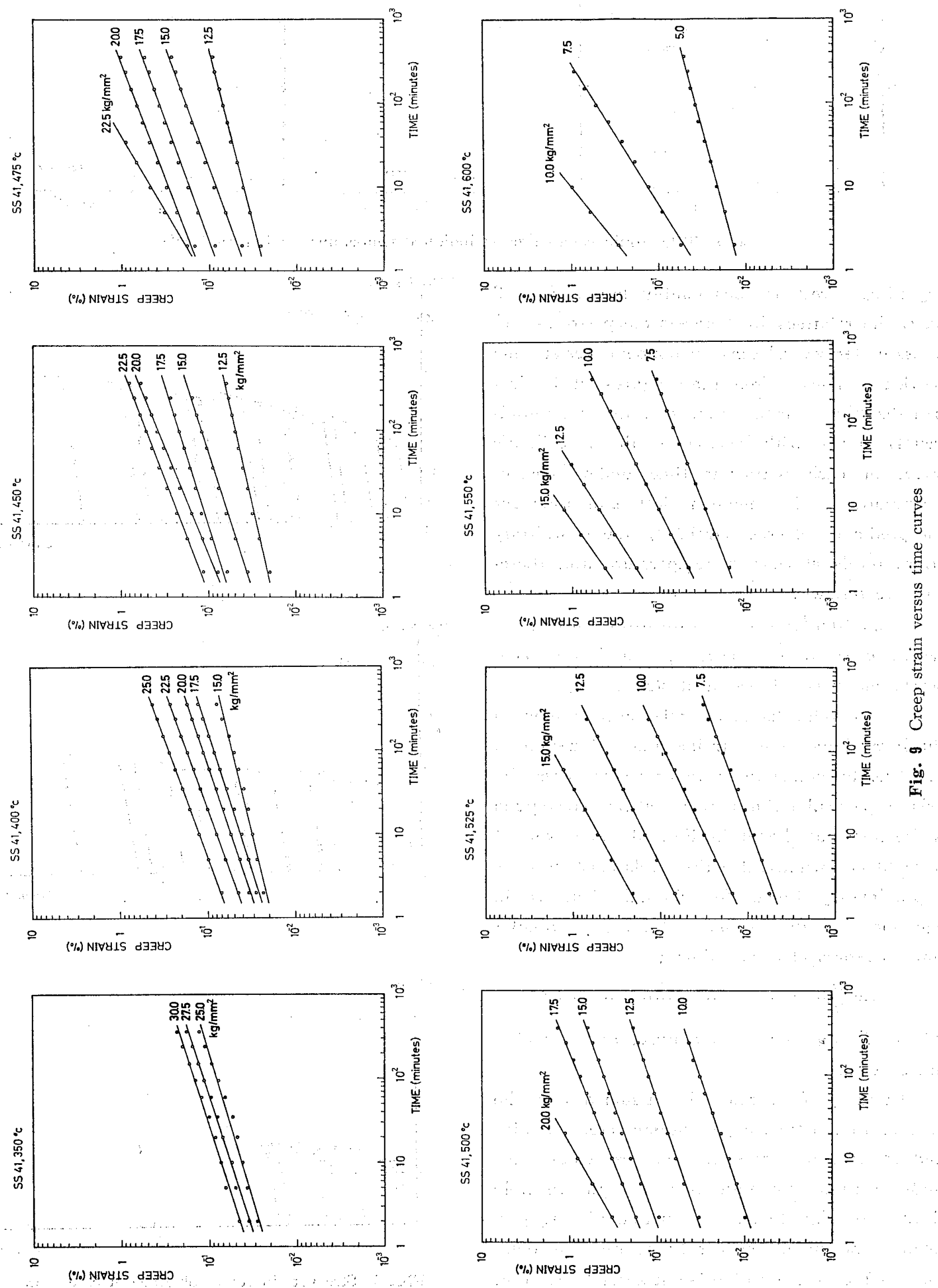


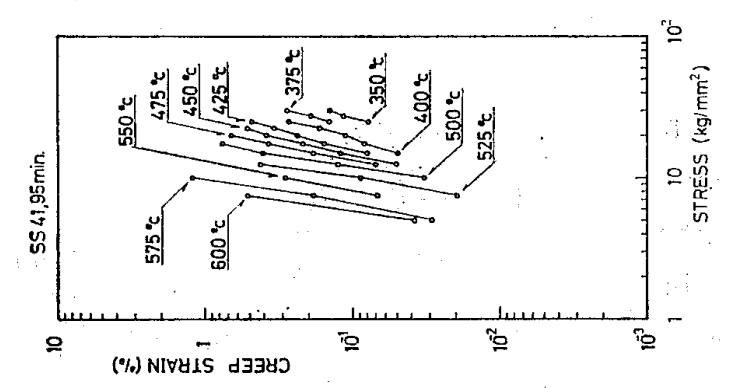

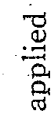
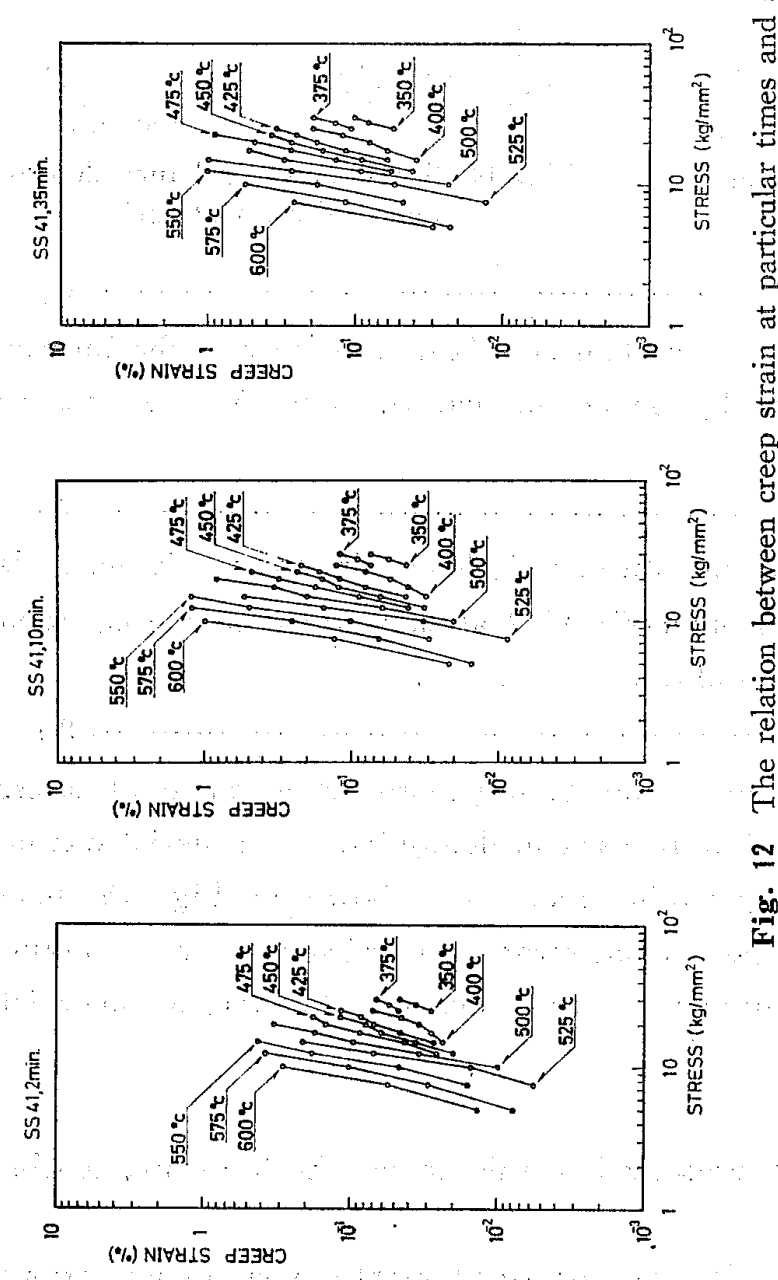

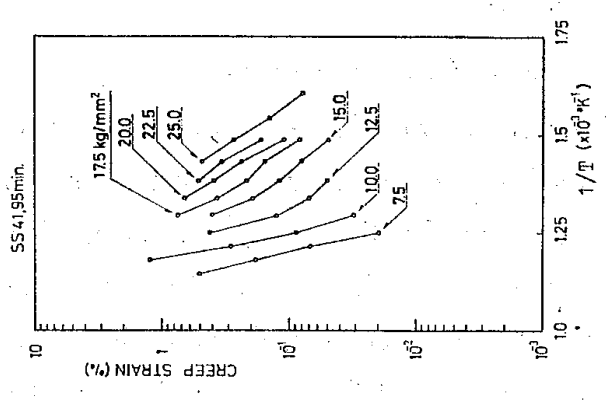

㐘
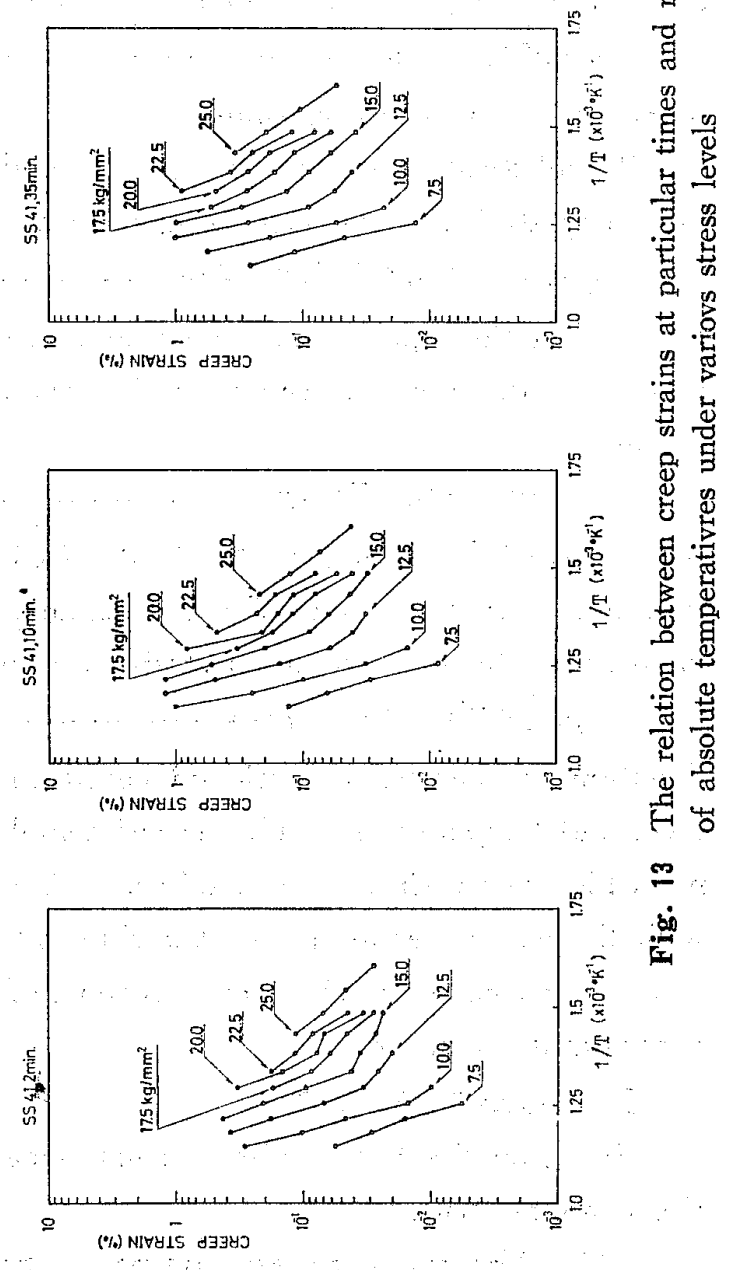

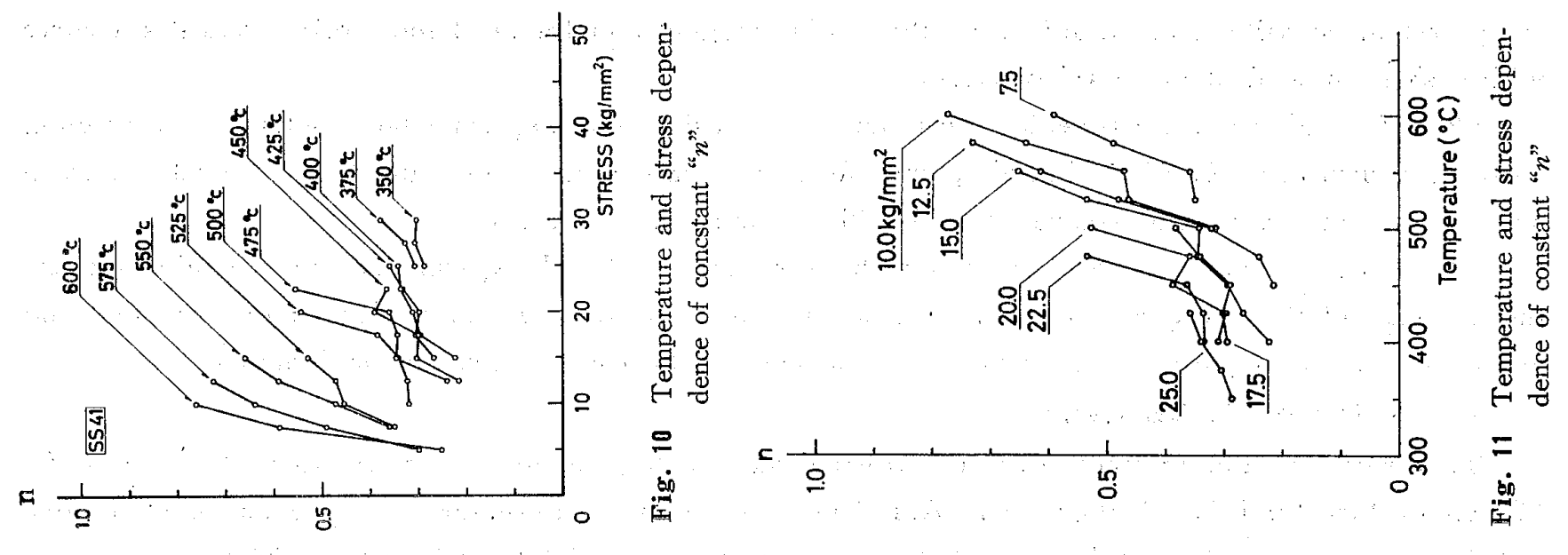




$$
B=\frac{c}{T}+d
$$

where $c$ and $d$ are constants.

Further, from Fig. 10 and 11, if it is assumed that the relationships between constant $n$ and stress and absolute temperature are approximately linear by attaching importance to the higher temperature range in which the creep deformation plays an important role in mechanical behaviour of structural members in fire and for simplification, $n$ in equation (2) under arbitrary stress and temeperature could be expressed as follows;

$$
n=e T+f+g \sigma
$$

where $e, f$ and $g$ are constants.

By substituting equations (3), (4) and (5) in equation (2), the creep strain, $\varepsilon_{c}$, is written as follows;

$$
\varepsilon_{c}=10^{a / T+b} \cdot \sigma^{c / T+d} \cdot t^{e T+f+g o}
$$

In this equation, $g \sigma$ in the expornent of time, $t$, has not so important significance because of the interaction with the other constants and variables. Therefore, by neglecting go, equation (6) becomes as follows;

$$
\varepsilon_{c}=10^{a / T+b} \cdot \sigma^{c / T+d} \cdot t^{e T+f}
$$

where $\varepsilon_{c}(\%)$ is primary creep strain, $T\left({ }^{\circ} \mathrm{K}\right)$ is absolute temperature, $\sigma\left(\mathrm{kg} / \mathrm{mm}^{2}\right)$ is stress, $t$ (minute) is time and $a, b, c, d, e$ and $f$ are constants. Nishihara and others ${ }^{(5)(6)(7)(8)}$ already proposed the equation to estimate the primary creep strain, $\varepsilon_{c}$, for mild steel as follows;

$$
\varepsilon_{c}=10^{a / T+b} \cdot \sigma^{c / T+d} \cdot t^{n}
$$

Fquation (7) has been developed based on equation (8) and is able to suit more wide range of stress level and temperature. The experimental results obtained were used to determine the material constants which were shown in Table 6. The calculated creep strain results are shown in Fig. 15 along with the experimental datas. Considering the possible experimental errors, the calculated creep strains were compared well with the experimental results, validating the expression for the various material constants uned above.

\section{CONCLU்SIONS}

Based on the test results and mathematical expression presented in this paper, the following conclusions can be made;

(1) The primary creep strains of structural steel, SS 41, were obtained quantitatively under various constant high temperature and stress levels.

(2) From the test results of stress-strain curves obtained with the creep curves, the relation between elastic-plastic strain and creep strain was clarified, that is, the stress-strain curve after the creep test arose with same gradient as the initial tangent and followed the virgin stress-strain curve with a short interval at low level of stress.

(3). A mathematical expression was developed, using the experimental results, for predicting creep of structural steel, SS 41, including the effects of temperature, stress and time. Calculated creep strains using this expression compared well with the experimental sesults.

(4) The comparatively good correlation between predicted and experimental creep strainsindicates the adequacy of the expression of creep of structural steel, SS 41. However, further experimental and analytical work is required before a more general mathematical expression can be formulated.

\section{ACKNOWLEDGEMENT}

This work on the primary creep of structual steel at high temperatures was carried out by W.G. "Creep of Structural Steel" (Chairman, Associate Prof. Fukujiro Furumura) of Metals Subcommittee (Chairman, Prof. Morihisa Fujimoto) of Reserch Committee on Safety of Structural Materials (Chair- 

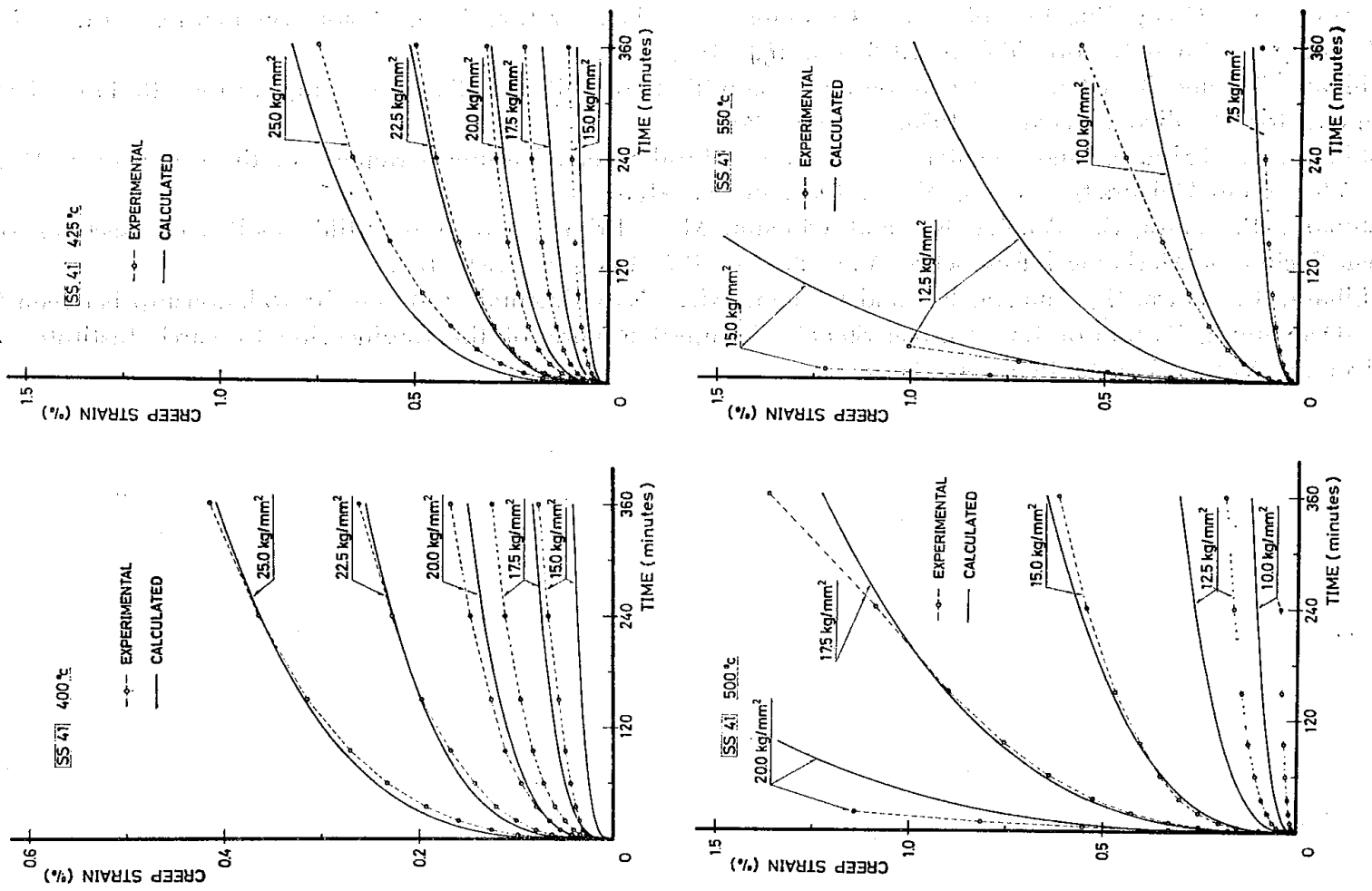

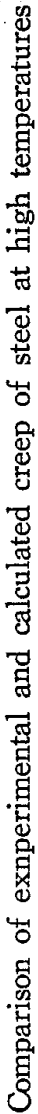
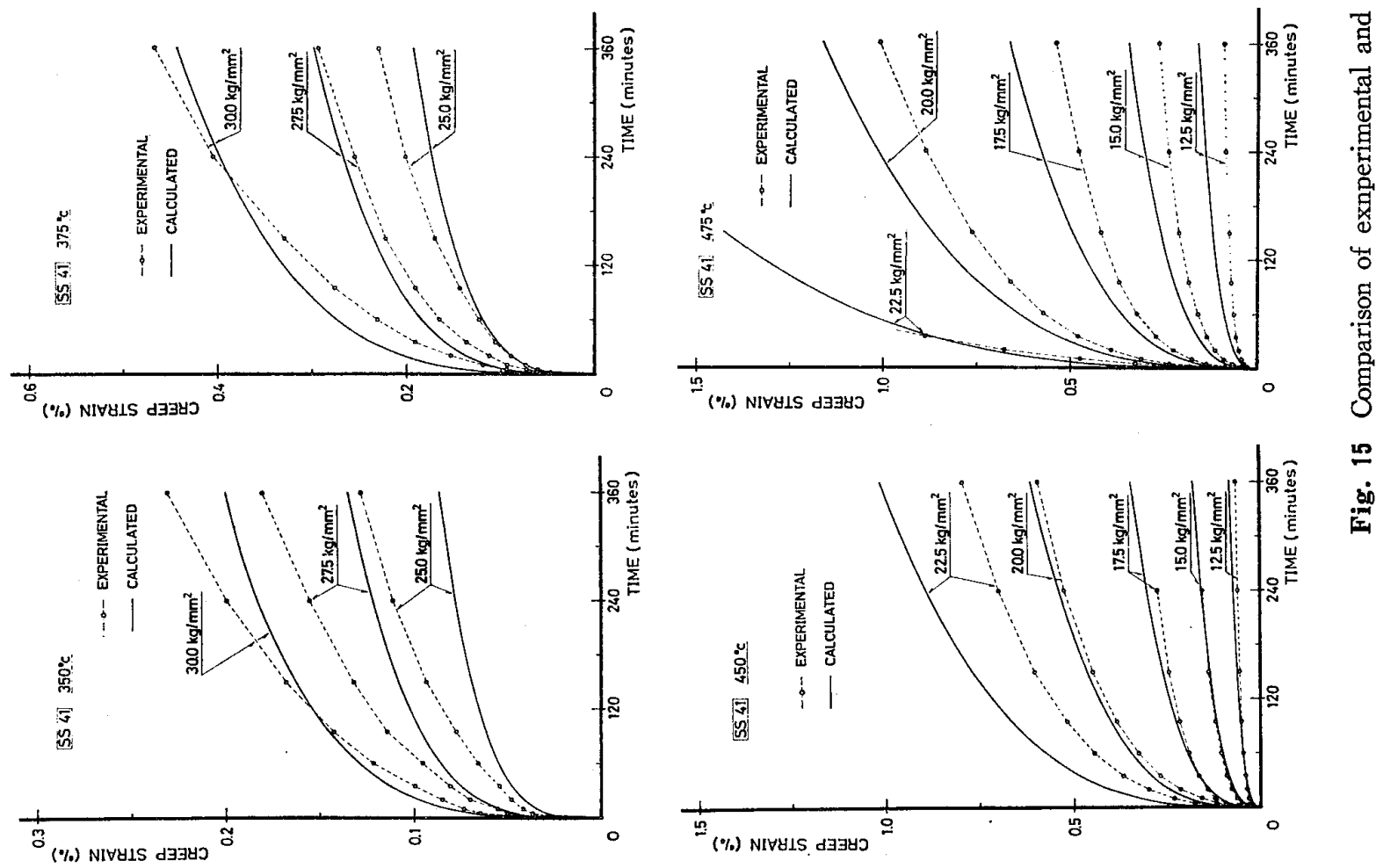

man, Prof. Takeo Naka) which was established in Japan Testing Center for Construction Materials, entrusted by Agency of Industrial Science and Technology.

The authors express their thanks to the Research Committee on Safety of Structural Materials for providing the necessary funds for the project.

\section{REFERENCES}

1) Furumura, F., and Shinohara, Y.: "Inelastic Behavior of Protected Steel Columns in Fire", Report of the Research Laboratory of Engineering Materials, No. 2, Tokyo Institute of Technology, 1977, pp. 45 61.

2) Furumura, F., and Shinohara, Y.; "Inelastic Behavior of Protected Steel Beams and Frames in Fire", Report of the Research Laboratory of Engineering Materials, No. 3, Tokyo Institute of Technology, 1978, pp. 1 14.

3) Eggwertz, S.; "Creep Buckling of Steel Column at Elevated Temperatures", IABSE 10th Congress, Preliminary Report, Tokyo, 1976, pp. 235 240. 
4) Eggwertz, S.; "Creep Buckling of a Steel Column in a Temperature-Time History Simulating a Fire", IABSE 10th Congress, Final Report, Tokyo, 1976, pp. 189 192.

5) Nishihara, T., and Tanaka, K.; "Tension and Creep Tests on Mild Steel", Proceedings of the 5th Japan National Congress for Applied Mechanics, 1955, pp. 199 201.

6) Nishihara, T., Taira, S., and Tanaka, K.; "Creep of Mild Steel", Technical Reports of the Engineering Research Institute, Kyoto University, Vol. 6, No. 6, 1956, pp. 99 125.

7) Nishihara, T., Taira, S., Tanaka, K., and Ohnami, M.; "Primary Creep of Mild Steel", Transactions of the Japan Society of Mechanical Engineers, Vol. 23, No. 127‘ 1957, pp. 154 159.

8) Nishihara, T., Taira, S., Tanaka, K., and Ohnami, M.; "Experimental Study on the Relationship between Creep Rate-Detemining Factors of Low Carbon Steel", Technical Reports of the Engineering Research Institute, Kyoto University, Vol. 8, No. 2, 1958, pp. 35 57. 


\section{高温度における構造用鋼材 (SS 41) の第一期 リープに関する実験（梗概）}

\begin{tabular}{|c|c|c|c|}
\hline 正 会員 藤 & 本 & 盛 & 久* \\
\hline 正会員 古 & 村 & 福 次 & 郎** \\
\hline 安 & 部 & 武 & 雄水水 \\
\hline 篠 & 原 & 保 & 二水** \\
\hline
\end{tabular}

\section{1. 序}

現行法規に従えば，構造部材の耐火性能の評価は，標 淮耐火試験（JIS A 1304）によって行われることになっ ている。しかしながら，標準耐火試験による構造部材の 耐火性能の評価は，実際の室内火災に抢ける構造部材の 而火性能とはむまり密接な関係にはない。

火災時に招ける高層建物の力学的挙動泟極めて複雑な ものであるので，この問題を合理的に解析し，火㷋に対 して，より優れた耐火設計を行えるようにするために は，以くつかの重要な基礎的研究を行ら必要がある。 その一つとして，鋼構造物の経時変形打よび高温クリ ープ挙動を，温度の関数としての材料の性質を用いて決 定することが出来る様にする事がある。そのためには， 構造用鋼材のクリープ性状に関する資料が必要となる。 しかしながら，火災時に扝ける鋼構造物の耐火設計に必 要なクリープデータは殆ど入手できない。

火炎時に打ける鋼構造物の力学的挙動をうまく解析で きるかどらか㤬，鋼のいくつかの力学的性質，特に温度 範囲，350 600 ${ }^{\circ} \mathrm{C}$ 間に括けるクリープ性状を如何に正 確に知るかによる。

それ故，本研究の主な目的は，代表的構造用鋼材のク リープ性状执よびクリープ歪と弾塑性歪の関係を明らか にすることにある。

この碖文では，一定荷重，一定温度下での構造用鋼材 のクリープ性状のうち， SS 41 材についての夕報告す る。

\section{2. 試 験 ·体}

構造用鋼材，SS 41 を用いた。試験体法 $25 \mathrm{~mm}$ 厚の 鋼板汃ら圧延方淌に削り出した。

試験体の形状・寸法は，図一1 亿示すとおりであり， 検長は， $50.8 \mathrm{~mm}$ である。鋼材の化学組成および力学 的性質を表一1 および 2 に示す。

\footnotetext{
* 東京工業大学 教授・杢博

** 東京工業大学 助教授・工博

**** 東尔工業大学大学院 院生・工修

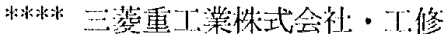

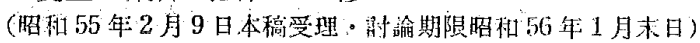

\section{3. 実験方法}

クリープ実験は，円笠形電気炉を㒂えたインストロン 型試験機を用いて行なった (図一 2,3 参照)。電気炉の 温度は自動温度コンドローラーによって調節され，実験 室は空調機にようて一定温度に制御されている。

電気炉内の試験体に試験機のクロスヘッドから荷重を 伝達させるための引張治具は耐熱鋼でできている。

歪の測定には特殊な高温歪計が用いられている。同歪 計は，ワイヤストレーンゲージ等による較正によって， 1000 分の $1 \mathrm{~mm}$ 程度までの測定精度があることが確か められている。炉内の空気の循環を最少限にするため に，加力治具や歪計の棒と炉の間は，繊維扮よび板状の 断熱材で充填されている。

実験は，350 $600^{\circ} \mathrm{C}$ の温度範囲に打いて $250^{\circ} \mathrm{C}$ 間隔 で行なった。各温度における作用応力は， $3 \sim 5$ 段階で， $2.5 \mathrm{~kg} / \mathrm{mm}^{2}$ の閊隔とした。原則として，各温度括よび 応力レベルについて試験体は 1 とし，試験時閒は 6 時間 とした。試験条件の一覽表を表一3 に示す。

\section{4. 実験結果}

試験機の記録計上に得たグリープおよびそれを同時に 測定した応力歪曲線の代表例を図一 4 に示す。

高温に打ける引張試験による危力歪曲線を参考のため に，図一5 に示す。その時の試験条件を表一 4 に示す。 試験は各温度につき 2 回行なった。これらの曲線から得 られた力学的性質を表一 5 に示寸。

SS 41 材のクリープ曲線全歪を図一6 抢よび 7 に示 す。これらの図において，一印は，応力が指定された レベルに達した点を示す。

クリープ曲線と同時にえられた㐫力歪曲線を図一8 K 示す。この図に扮いて水平な線は，クリープ歪を示して 扔り，それに続く曲線は，クリープ試験が終了したのち に得られた応力歪曲線である。

これらの図から，クリープ歪と弾塑性歪の関係が明ら かにされる。つまり，クリープ変形後の応力歪曲線は, 初期切線と同じ勾配で立ち上がり，艺の後，处女応力歪 曲線をやや下側から追跡する形のものとなる。 
クリープ歪は，忘力，温度および時間の影響をらけ る。構造用鋼材の第一期クリープに対する時間の影響 は, 試験開始から 30 分以内で特に顕著である。クリー プ歪は $450^{\circ} \mathrm{C}$ 以上の高温で著しく大きくなるので，火 災時における鋼構造物の熱店力の解析にあたっては; こ れを無視することはできない。また，怘力レベルがその 温度での鋼材の比例限度を越えると，クリープ歪は急激 に増大する。

\section{5. クリープ歪推定式}

図一9にクリープ歪と時閒の関係を対数グラフ上に示 す。これらの図から，対数クリープ歪と対数時間とは， 各々の温度㧍よび応力レベルにおいて, ほぼ直線関倸に あり，次のように書き表わせる。

$$
\varepsilon_{c}=10^{A} t^{n}
$$

ここで， $\varepsilon_{c}$ はクリープ歪で， $t$ は時閒であり，Aお よび $n$ は定数である。温度一定で応力レベルが変化した 場合，これらの直線の勾配むをた変動する。図一10 お よび 11 は, 式（1）における定数 $n$ が, 各温度におい て，応力レベルの変化と共にどのように変化するか，拉 よび各応カレベルにおいて，温度の変化と共にどのよう に変化するかを示している。 $n$ は一般には，応力と温 度の関数である。しかしながら，比較的低い温度範囲 $\left(350 \sim 500^{\circ} \mathrm{C}\right)$ においては, 応力の変化による $n$ の変化 は，一定温度下においては比較的小さい。このことは， 図一9 に执いて，一定温度下でのいくつかの応力レベル での直線群が注ぼ平行であることを意味する。しかしな がら比較的高温 $\left(525 \sim 600^{\circ} \mathrm{C}\right)$ に打いては，态力に関す る $n$ の変動動はかなり大きい。

図一12: は，いくつかの特定の時間および一定温度下 でのクリープ歪と応力の関係を示している。これらの図 から, 対数クリープ歪と対数応力とは, 各々の特定の時 閒に扣いて，一定温度下では，ほぼ直線関係にあること が分かる。それ故, 一定温度下で, 任意の応力レベル下 でのクリープ歪, $\varepsilon_{c}$, の推定式は炏のようになる。

$$
\varepsilon_{c}=10^{A} \cdot \sigma^{B} \cdot t^{n}
$$

ここで, $\sigma$ は応力, $t$ は時間, $A$ および $B$ は定数, $n$ は応力の関数である。

一方, 特定の時間における, いくつかの応力レベルで の対数クリープ歪と絶対温度の逆数の関係は， 図-13 に示すように，必ずしも常に直線関係にあるとは考えら れない。しかしながら，単純化のためにこれらの関係 は，ほぼ直線関倸にあるものと仮定すれば，特定の時間 に拉ける一定応力下での式 (2) の中の $A$ は, 次の上う に表わせる。

$$
A=\frac{a}{T}+b
$$

ここで， $T$ は絶対温度であり， $a$ および $b$ は定数で ある。
さらに，いくつかの特定の時閒における一定温度下で の対数クリープ歪と対数応力の関係は，ほぼ直線関係に 女るものと仮定すれば（図-12 参照），特定の時間にお ける一定温度下での式 (2) の中の $B$ は，これらの直線 の勾配として得られる。図一14 は，式（2）の中の $B$ が, いくつかの特定の時間に㧊いて, 絶対温度の逆数の 変化と共にどのように変化するかを示している。図一14 から，B と絶対温度の逆数との関係は，非常に複雑であ ることが分かる。しかし，単純化のために，これらの関 係は，ほぼ直線関係にあるものと仮定すれば，特定の時 間に抢ける式（2）の中の $B$ は，次のように表わせる。

$$
B=\frac{c}{T}+d
$$

\section{ここで，cおよびdは定数である。}

また，図一10 抢よび 11 から，定数 $n$ と応力㧤よび 絶対温度の関倸は，クリープ変形が，火㷋時における構 造部材の力学的挙動に重要な役割を果た寸比較的高温領 域に重点を置くことおよび推定式の単純化のため，ほぼ 直線関係にあるものと仮定すれば，任意の応力および温 度下においては, 式 (2) の中の $n$ は, 次のように表わ される。

$$
n=e T+f+g \sigma
$$

ここで, $e, f$ および $g$ は定数である。

式（2）に式（3)，(4) および（5）を代大することに よって, クリープ歪 $\varepsilon_{c}$, は, 次のように書ける。

$$
\varepsilon_{c}=10^{a / T+b} \cdot \sigma^{c / T+d} \cdot t^{e T+f+g \sigma} .
$$

上式に括いて，時間 $t$ の指数中の $g \sigma$ は，他の定数 や変数との相互作用のために，必ずしも重要な意味をむ たない。したがって，式の単純化も考えて，go の項を 無視すると，(5) 式は次のようになる。

$$
\varepsilon_{c}=10^{a / T+b} \cdot \sigma^{c / T+d}, \cdot t^{c T+f}
$$

ここで $\varepsilon_{c}(\%)$ は第一期クリープ歪， $T\left({ }^{\circ} \mathrm{K}\right)$ は絶対 温度, $\sigma\left(\mathrm{kg} / \mathrm{mm}^{2}\right)$ は応力, $t$ (分) अ時間で, $a, b, c, d$, $e$ および $f$ は定数である。

西原 ${ }^{5}$ ） らは，軟鋼に対する第一期クリープの推定式 として，次式を提案している。

$$
\varepsilon_{c}=10^{a / T+b} \cdot \sigma^{c / T+d}, \cdot t^{n}
$$

(7) 式は（8）式を更に発展させたるのであり，一層広 い态力や温度範囲に対して適用可能である。

得られた実験デー夕を基に材料定数を求めた結果を表 -6 に示す。計算クリープ歪を, 図一 15 に, 実験デー タと比較して示す。実験愦差を考慮すれば，計算クリ一 プ歪将実験結果とよく一致して扔り，推定式の有効性を 示している。

\section{6. 結論}

この論文で示した㬰験結果およびクリープ歪推定式に 基づいて次の結論が導きだされた。

（1）種々の温度および応力下での構造用鋼材（SS 
41 材）の第一期クリープ歪を定量的に求めることがで きた。

（2）クリープ曲線と同時に求めた応力歪曲線から, 弹塑性歪とクリープ歪間の関係を明らかにすることがで きた。つまり, クリープ試験後の応力歪曲線は, 初期切 線と同じ勾配で立ち上がり, その後, 処女応力歪曲線を やや下側から追跡する形となる。

（3）温度，忘力および時間の影響を含んで，鋼材 （SS 41）の第一期クリープ歪を推定する式を実験結果を 基に誘導した。この式を用いての計算クリープ歪は実験
值とかなりよい一致を示した。

（4）クリープ歪の実験值括よび計算值の閒の比較的 上い相関関係は, 鋼のクリープ推定式の妥当性を示して いる。しかしながら，更に一般的なクリープ推定式を提 示するためには，一層多くの実験と解析が必要である。 最後に, 本実験は, 通産省, 建材試験センター, JMC 委員会 (委員長 仲威雄東大名資教授)，金属分科会（主 查 藤本), 高温クリープ部会 (主查 古村) の昭和 51 年 度研究費で行なったものであり，関係者に謝意を表す る。 